\title{
Rapid adaptation reduces perceived odor intensity in rodents
}

\author{
Yevgeniy Sirotin \\ From 1st International Workshop on Odor Spaces \\ Hannover, Germany. 4-7 September 2013
}

While most information about olfactory perception comes from human psychophysics, most neurophysiological understanding of neural odor coding comes from rodents. Intensity perception in humans is known to undergo rapid adaptation in as little as a single inhalation of odor. In rodents, odor-driven neural responses change rapidly across sniffs, but it is unclear whether these changes are associated with reductions in perceived odor intensity. To address this issue, we used a behavioral assay in rats to measure changes in the relative intensity of two odors as a function of concentration and after rapid adaptation. We show that a brief $300 \mathrm{~ms}$ exposure to an adapting odor immediately reduces the perceived intensity of the same odor relative to an unrelated control odor. This drop in relative intensity is similar to a 10 -fold dilution of the test odor. Our data show that perceived odor intensity in rodents changes rapidly following odor onset, possibly in just one sniff. This provides a potential perceptual correlate to rapid changes in odor responses observed in neurophysiological investigations of odor coding.

Published: 16 April 2014

doi:10.1186/2044-7248-3-S1-P18

Cite this article as: Sirotin: Rapid adaptation reduces perceived odor intensity in rodents. Flavour 2014 3(Suppl 1):P18.

Submit your next manuscript to BioMed Central and take full advantage of:

- Convenient online submission

- Thorough peer review

- No space constraints or color figure charges

- Immediate publication on acceptance

- Inclusion in PubMed, CAS, Scopus and Google Scholar

- Research which is freely available for redistribution

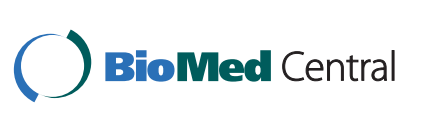

